\title{
The impact of aging on laboratory fire behaviour in masticated shrub fuelbeds of California and Oregon, USA
}

\author{
Jesse K. Kreye ${ }^{\mathrm{A}, \mathrm{B}, \mathrm{G}}$, J. Morgan Varner ${ }^{\mathrm{B}, \mathrm{C}}$, Jeffrey M. Kane ${ }^{\mathrm{D}}$, Eric E. Knapp ${ }^{\mathrm{E}}$ \\ and Warren P. Reed ${ }^{\mathrm{A}, \mathrm{F}}$ \\ A Present address: Department of Forest Resources and Environmental Conservation, \\ Virginia Tech, Blacksburg, VA 24061, USA. \\ ${ }^{B}$ Forest and Wildlife Research Center, Mississippi State University, Box 9681, Mississippi State, \\ MS 39762, USA. \\ CUSDA Forest Service, Pacific Northwest Research Station, Pacific Wildland Fire Sciences \\ Laboratory, Seattle, WA 98103, USA. \\ Department of Forestry and Wildland Resources, Wildland Fire Laboratory, \\ Humboldt State University, Arcata, CA 95521, USA. \\ ${ }^{E}$ USDA Forest Service, Pacific Southwest Research Station, Redding, CA 96002, USA. \\ F Department of Ecosystem Science and Management, Pennsylvania State University, \\ University Park, PA 16802, USA. \\ GCorresponding author. Email: jkk139@vt.edu
}

\begin{abstract}
Mastication of shrubs and small trees to reduce fire hazard has become a widespread management practice, yet many aspects of the fire behaviour of these unique woody fuelbeds remain poorly understood. To examine the effects of fuelbed aging on fire behaviour, we conducted laboratory burns with masticated Arctostaphylos spp. and Ceanothus spp. woody debris that ranged from 2 to 16 years since treatment. Masticated fuels that were 10 years or older burned with 18 to $29 \%$ shorter flame heights and $19 \%$ lower fireline intensities compared with the younger fuelbeds across three different fuel loads $\left(25,50\right.$ and $\left.75 \mathrm{Mg} \mathrm{ha}^{-1}\right)$. Older fuelbeds smouldered for almost $50 \%$ longer than the younger masticated fuelbeds. Fuel consumption was $96 \%$ in the two higher fuel load categories regardless of fuelbed age, whereas consumption was $77 \%$ in the lighter fuel load. Fire intensity in masticated fuels may decrease over time owing to particle degradation, but in dry environments where decomposition is slow, combustion of the remaining fuels may still pose risks for tree mortality and smoke production associated with protracted smouldering.
\end{abstract}

Additional keywords: fireline intensity, fuel decomposition, fuels treatments, mechanical mastication, smouldering combustion.

Received 8 December 2015, accepted 20 May 2016, published online 5 July 2016

\section{Introduction}

Mastication is a mechanical treatment that alters fuel structure through shredding or chipping understorey shrubs and small trees, redistributing fuels from the midstorey to the surface (Kane et al. 2009; Kreye et al. 2014a). Mastication treatments are increasingly being used in fire-prone environments across the USA (Kane et al. 2009; Kobziar et al. 2009; Battaglia et al. 2010; Menges and Gordon 2010; Brewer et al. 2013; Kreye and Kobziar 2015) and elsewhere (Molina et al. 2009; Montiel and Kraus 2010; Schiks et al. 2015). Mastication often creates heavy but compact fuelbeds composed of shredded woody material with a high proportion of small-diameter particles (Kreye et al. 2014b). Compaction of the fuelbed is predicted to change fire behaviour (Knapp et al. 2011). Although mastication can lower flame lengths under some burning conditions in comparison with untreated vegetation (Kreye and Kobziar 2015), intense fire behaviour has also been observed during laboratory (Kreye et al. 2011, 2013) and field-based (Bradley et al. 2006) burning experiments. Substantial overstorey mortality (Knapp et al. 2011) and significant soil heating (Busse et al. 2005) can result when masticated fuels are burned. Following treatment, masticated fuels typically remain on site until they decompose or are consumed by subsequent prescribed burning (Reiner et al. 2009; Knapp et al. 2011). Understanding the fate of these surface fuels and how their combustion properties change over time is essential to determine the efficacy and longevity of mastication.

Laboratory experiments have revealed some of the effects of particle- or fuelbed-scale properties on fire behaviour in masticated fuels (Busse et al. 2005; Kreye et al. 2011; Kreye et al. 2013), but no studies have examined how fuelbed age influences fire behaviour. As masticated woody fuels decompose, reductions in loading should dampen fire behaviour. 
With decomposition, physical properties of fuels such as particle density, lignin : cellulose ratio and mineral content also change (particularly in the more rapidly decomposing fine fuels; Carlton and Pickford 1982; Erickson et al. 1985; Zhao et al. 2014; Keane 2015). And as particles become less dense and finer particles are more rapidly lost, fuelbed properties such packing ratio (Rothermel 1972) and average particle surface area: volume may also change. These altered fuel properties may change fire behaviour in ways beyond simple reductions in total fuel loading. Understanding how these fuelbed age factors contribute to the intensity and duration of energy release while burning will provide important information regarding posttreatment fire behaviour and aid in developing fuel models to better predict fire behaviour and effects (Kreye et al. 2014b).

The objective of the present study was to quantify, through laboratory experiments, the effects of fuelbed age on energy release (fireline intensity), flame height, flaming duration and smouldering duration in masticated debris collected from sites ranging from 2 to 16 years since mastication. Our specific aim was to understand how changes in the physical properties of particles and alterations in fuelbed composition would influence fire behaviour beyond the expected changes in fuel load. We hypothesised that fuelbeds composed of material collected from older masticated sites would burn with lower fireline intensities and shorter flame lengths and for a longer duration as a result of particle-level degradation. We tested the combined effects of physical changes to masticated particles, by collecting in situ material, and changes to fuelbed composition, by altering 1-h $(<0.64 \mathrm{~cm})$ and $10-\mathrm{h}(0.64-2.54 \mathrm{~cm})$ fuel proportions according to field measurements at sites of varying fuelbed age. We conducted burning experiments using three levels of fuel loading that approximated high-loading sites in the field.

\section{Methods}

\section{Fuel collection sites}

Masticated woody fuels were collected from four treatment areas to evaluate the effect of fuelbed age on fire behaviour during controlled laboratory burn experiments. Mastication treatments were conducted in 2012 (Six Rivers National Forest, California), 2010 (Shasta-Trinity National Forest, California), 2004 (Shasta-Trinity National Forest) and 1998 (Applegate Valley, Bureau of Land Management, Oregon). All sites are located within the Klamath Mountains-California High Coast Range Level III ecoregion (United States Environmental Protection Agency 2013). The maximum distance between sites is $272 \mathrm{~km}$. Although overstorey conditions varied, the midstorey vegetation that was targeted for mastication was dominated by Arctostaphylos spp. and Ceanothus spp. shrubs at all sites. Composition of masticated woody debris (i.e. proportion by size class) and specific gravity of masticated particles were evaluated across these sites by Reed (2016) as part of a larger study examining fuel dynamics following mastication in the region.

\section{Experimental burning}

Collected woody fuels were used to create laboratory-scale $(25 \times 25-\mathrm{cm})$ fuelbeds for burning experiments. The proportion of fuel by size class (1- and 10-h) was consistent with regional changes over time observed by Reed (2016). Because 100-h fuels were less common across sites (only $12-20 \%$ by mass), we only used 1- and 10-h fuels for experimental burns, similarly to previous burning experiments (Kreye et al. 2011). As collected material from each site was used for experimental burns, our fuelbeds reflected changes to particle density and other chemical and physical changes. We did not mimic total fuel loading across the sites from which fuel was collected, but rather tested the effect of fuelbed age as reflected in fuelbed composition and fuel particle density across three total fuel loads $(25,50$ and $75 \mathrm{Mg} \mathrm{ha}^{-1}$ ) that spanned the upper range observed in masticated sites across the region (Kane et al. 2009; Reed 2016). Therefore, our laboratory experiments allowed us to isolate effects of particle degradation as fuelbeds age, such as a reduction in particle density and the loss of 1-h woody particles. Fuel composition (percentage 1-h by weight) varied by fuelbed age to reflect fuelbed degradation observed by Reed (2016) with $2-, 4-, 10$ - and 16-year-old fuels resulting in 36, 32, 24 and 16\% 1-h fuels respectively. Specific gravity of the 2-, 4-, 10- and 16-year-old fuels averaged $0.69,0.69,0.51$ and 0.52 for 10 -h particles and $0.67,0.59,0.49,0.45$ for the 1 -h particles (Reed 2016).

Fuelbeds were burned within combustion boxes $(25 \times 30 \times$ $15 \mathrm{~cm}$ inside dimensions, Fig. 1) lined with 13-mm-thick cement

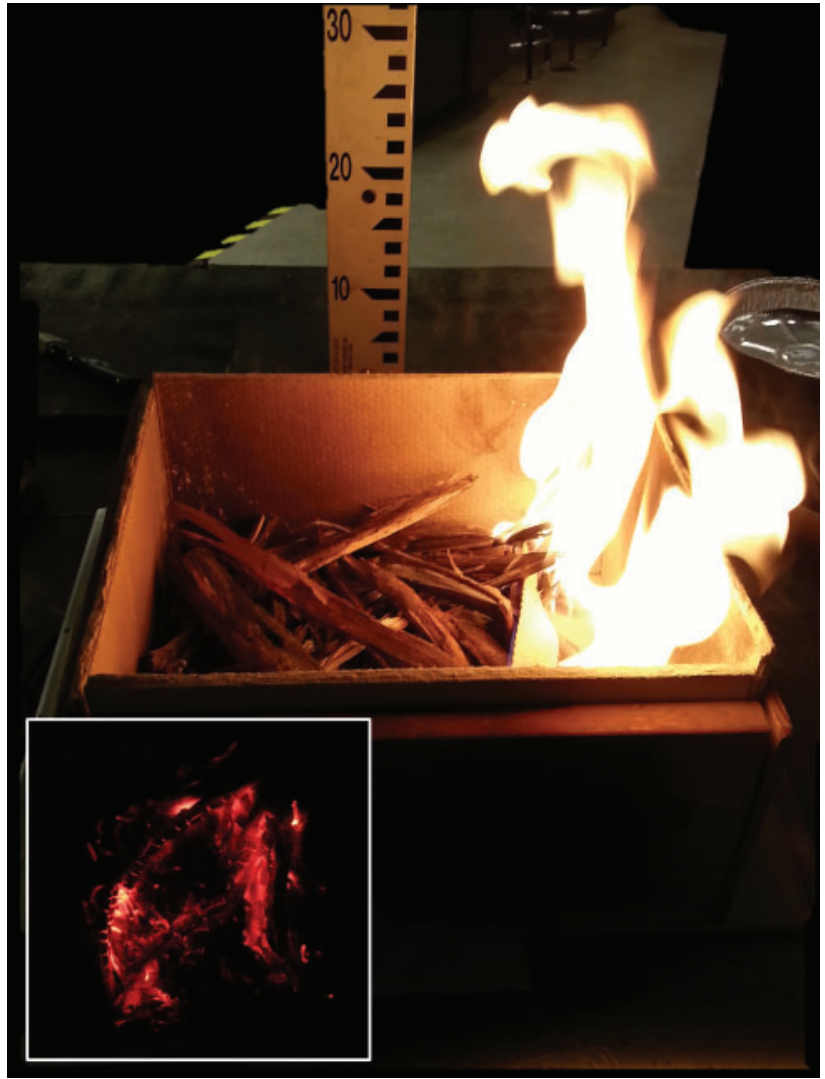

Fig. 1. Laboratory burning of masticated shrub fuelbeds. Fuelbeds were ignited along one edge utilising a flat paraffin-soaked wick (visible along the right edge of fuelbed) and flame heights ocularly estimated during burning (rule gradations are in $\mathrm{cm}$ ). Mass loss was recorded via a bench scale interfaced with a computer. Insert: smouldering and glowing combustion followed flaming. 
board along the bottom and sides. Fuelbeds were arranged against one edge of the combustion box, leaving $5 \mathrm{~cm}$ of open space along which ignition occurred. Masticated particles within sites were randomly selected and composited to create fuelbeds. For each site, fuelbeds were created with three fuel load treatments: 156 , 313 and $469 \mathrm{~g}$ of fuel, corresponding to total loads of 25, 50 and $75 \mathrm{Mg} \mathrm{ha}^{-1}$ respectively. Bulk density $\left(\mathrm{kg} \mathrm{m}^{-3}\right)$ of fuelbeds was calculated from fuelbed depth and total fuel mass. Fuels were at laboratory moisture conditions $(5.9 \pm 0.6 \%$ gravimetric moisture content across all fuel sizes, based on 22 random samples) when burned. Experiments were replicated three times within each fuel load and fuelbed age combination, for a total of 36 burns.

Fuelbeds were ignited using a flat $2.5 \times 20$-cm lamp wick soaked in $99 \%$ pure paraffin wax along the open edge (Fig. 1), as in Kreye et al. (2011); wicks burned for $\sim 10$ s. During burn experiments, we recorded maximum flame height $(\mathrm{cm})$, observed against a vertically oriented ruler (Fig. 1); flaming time (s, time elapsed from ignition to flame extinction); and smouldering time ( $\mathrm{s}$, time elapsed from the end of flaming to the end of glowing combustion that was visible under darkened conditions). Following smouldering combustion, we weighed the remaining fuel mass and calculated percentage consumption. To estimate energy release, burns were conducted on top of a bench scale connected to a computer (RS232 interface) and weight was recorded throughout burning at 5-s intervals. Energy release was calculated as fireline intensity $\left(\mathrm{kW} \mathrm{m}^{-1}\right)$ by multiplying mass loss (g) per 5-s interval by a representative heat content (19.2 $\mathrm{kJ} \mathrm{g}^{-1}$; Countryman 1982) divided by the width $(0.25 \mathrm{~m})$ of the fuelbed, as described in Kreye et al. (2011). All 36 experimental burns were conducted in a randomised order.

\section{Data analysis}

Fire behaviour metrics (peak fireline intensity, flame height, flaming duration, smouldering duration and fuel consumption) were each compared across fuelbed age and total fuel load category $\left(25,50,75 \mathrm{Mg} \mathrm{ha}^{-1}\right)$ using a general linear model
(GLM) analysis of variance. Main effects and their interactions were examined. Although burns were conducted in a laboratory, ambient conditions varied somewhat; air temperature ranged from 21.5 to $24.5^{\circ} \mathrm{C}$ and relative humidity ranged from 42 to $52 \%$. Both temperature and relative humidity were tested as covariates in each analysis. Relative humidity was a significant covariate for flame heights $(P<0.001)$, and GLM analysis of covariance subsequently used, but not for any other fire behaviour metric. Air temperature was not a significant covariate in any analysis. Fuelbed bulk density was confounded with fuelbed age and fuel load treatments (see Results); we therefore report bulk density values, but do not evaluate it as a dependent variable. Differences among the means were examined using the Tukey-Kramer posthoc multiple comparison test. Significance for all analyses was tested at $\alpha=0.05$. Normality of residuals and homoscedasticity (GLM assumptions) were confirmed for each analysis using the Shapiro-Wilk test and modified Levene test respectively.

Fireline intensity was evaluated throughout the duration of flaming combustion using LOESS (locally weighted regression scatter-plot smoothing) curve-fitting across replicated burns. Whereas peak fireline intensity indicates the maximum energy output within one 5-s interval for each burn, the LOESS regression provides weighted average fireline intensities throughout burning across replicates (Kreye et al. 2011).

\section{Results}

Bulk densities across all fuelbeds averaged $82.8 \mathrm{~kg} \mathrm{~m}^{-3}$ (18.9 s.d.) with differences only detected between the lowest fuel load (25 $\mathrm{Mg} \mathrm{ha}^{-1}$ ), averaging $66.7 \mathrm{~kg} \mathrm{~m}^{-3}$, and the two highest fuel loads $(P<0.001)$, which averaged 85.8 and $95.8 \mathrm{~kg} \mathrm{~m}^{-2}$ for the 50 and $75 \mathrm{Mg} \mathrm{ha}^{-1}$ fuelbeds respectively; and between the 4- and 16-year-old fuels $(P=0.001)$, which averaged 71.1 and $92.2 \mathrm{~kg} \mathrm{~m}^{-3}$ respectively. Maximum flame heights of the masticated fuelbeds ranged from 15 to $80 \mathrm{~cm}$ and peak fireline intensities from 31 to $138 \mathrm{~kW} \mathrm{~m}^{-1}$ across the 36 experimental burns. As expected, flame heights and peak fireline intensities

Table 1. Fire behaviour metrics during laboratory experimental burning of 25,50 and $75 \mathrm{Mg} \mathrm{ha}^{-1}$ of masticated fuelbeds collected from sites with varying fuelbed ages $(2,4,10$ and 16 years)

Values shown are adjusted means for each level of the main effects (fuel age and fuel load) from general linear modelling (GLM) analysis of variance. Different superscript letters within fuel age or fuel load, for each burn metric separately, indicate significant differences based on Tukey-Kramer post-hoc multiple comparison tests. No interactions between main factors (fuel age, fuel load) were significant for any burning metric

\begin{tabular}{|c|c|c|c|c|c|}
\hline Factor & $\begin{array}{l}\text { Maximum flame height } \\
\qquad(\mathrm{cm})\end{array}$ & Flaming duration & $\begin{array}{l}\text { Smouldering duration } \\
(\mathrm{min})\end{array}$ & $\begin{array}{l}\text { Fuel consumption } \\
(\%)\end{array}$ & $\begin{array}{l}\text { Peak fireline intensity } \\
\qquad\left(\mathrm{kW} \mathrm{m}^{-1}\right)\end{array}$ \\
\hline \multicolumn{6}{|c|}{ Fuel age (years) } \\
\hline 2 & $55^{\mathrm{a}}$ & $14.8^{\mathrm{a}}$ & $51^{\mathrm{a}}$ & $89^{\mathrm{a}}$ & $85.3^{\mathrm{ab}}$ \\
\hline 4 & $52^{\mathrm{ab}}$ & $13.0^{\mathrm{a}}$ & $62^{\mathrm{ab}}$ & $91^{\mathrm{a}}$ & $92.2^{\mathrm{a}}$ \\
\hline 10 & $45^{\mathrm{bc}}$ & $13.2^{\mathrm{a}}$ & $73^{\mathrm{bc}}$ & $87^{\mathrm{a}}$ & $76.8^{\mathrm{b}}$ \\
\hline 16 & $39^{\mathrm{c}}$ & $15.4^{\mathrm{a}}$ & $74^{\mathrm{bc}}$ & $87^{\mathrm{a}}$ & $73.4^{\mathrm{b}}$ \\
\hline \multicolumn{6}{|c|}{ Fuel load $\left(\mathrm{Mg} \mathrm{ha}^{-1}\right)$} \\
\hline 25 & $27^{\mathrm{a}}$ & $13.4^{\mathrm{a}}$ & $49^{\mathrm{a}}$ & $77^{\mathrm{a}}$ & $48.6^{\mathrm{a}}$ \\
\hline 50 & $51^{\mathrm{b}}$ & $14.6^{\mathrm{a}}$ & $66^{\mathrm{b}}$ & $93^{\mathrm{b}}$ & $84.5^{\mathrm{b}}$ \\
\hline 75 & $65^{\mathrm{c}}$ & $14.2^{\mathrm{a}}$ & $79^{\mathrm{b}}$ & $96^{\mathrm{b}}$ & $112.6^{\mathrm{c}}$ \\
\hline
\end{tabular}


were also strongly correlated $(P<0.001, r=0.862)$. Flaming and smouldering durations ranged from 8.7 to 21.3 and 35 to 121 min respectively. Fuel consumption across the chronosequence ranged from 51 to $97 \%$.

Fuelbed age had a negative influence on maximum flame height $(P<0.001)$ and peak fireline intensity $(P=0.004)$, but positively affected smouldering time $(P=0.010)$ across all fuel loads (Table 1, Fig. 2). Flame heights were shorter in the two oldest (10- and 16-year) fuels compared with the youngest (2-year-old) fuels. Four-year-old fuels also burned with taller flames compared with the oldest (16-year) masticated fuels and peak fireline intensities were greater in the 4-year-old fuels compared with both the older (10- and 16-year) fuels. Although fuelbed age did not affect flaming duration $(P=0.345)$, these older fuels smouldered for $\sim 50 \%$ longer than the most recently masticated debris (Table 1). Fuelbed age did not affect fuel consumption $(P=0.846)$, which averaged $89 \%$.

Flame heights and peak fireline intensities differed across all fuel loads $(P<0.001)$, with heavier fuelbeds burning with taller flames and greater fireline intensity (Table 1, Fig. 2). Flaming duration, however, did not differ among fuel loads $(P=0.660)$, but the lighter $25-\mathrm{Mg} \mathrm{ha}^{-1}$ fuelbeds smouldered for shorter durations and were less consumed compared with the heavier 50 - and $75-\mathrm{Mg} \mathrm{ha}^{-1}$ fuelbeds $(P<0.001)$. No interactions were detected between fuelbed age and fuel load on flame heights $(P=0.981)$, flaming duration $(P=0.910)$, smouldering duration $(P=0.269)$, fuel consumption $(P=0.591)$ or peak fireline intensity $(P=0.281)$.

Fireline intensity throughout burning (based on LOESS regression curves) also trended towards diminished energy release in the older fuels across all three fuel load categories (Fig. 3). The 4-year-old fuels, however, consistently burned with greater intensity than younger 2-year-old fuels. Similar results were apparent in peak fireline intensities observed during burning of the $50-$ and $75-\mathrm{Mg} \mathrm{ha}^{-1}$ loads (Fig. 2), but these differences were not significant in a Tukey-Kramer post hoc comparison of the means.

\section{Discussion}

The present study revealed a reduction in fireline intensity with fuelbed age following mastication of shrub-dominated fuels. Recently masticated fuels burned similarly in flame height, fireline intensity and consumption to that of other recently masticated Arctostaphylos spp. and Ceanothus spp. fuels from a previous study (Kreye et al. 2011). Changes in particle-level properties and the relative loss of 1-h particles in fuelbeds over time both likely contributed to fuelbed age dampening fire behaviour (Rothermel 1972). These factors are confounded in the present study, however, and the mechanisms involved may be complex. As average particle surface area : volume decreases with losses in 1-h fuels, combustion rates are likely to decrease (Rothermel 1972). But reductions in particle density and increases in fuelbed bulk density, characteristics of older fuelbeds in the current study, both increase fuelbed packing ratio. And reaction intensity has been shown to increase with packing ratio to an optimum beyond which intensity then decreases (Rothermel 1972). It is unknown what the optimum packing ratio may be for these masticated fuels. Reduced particle
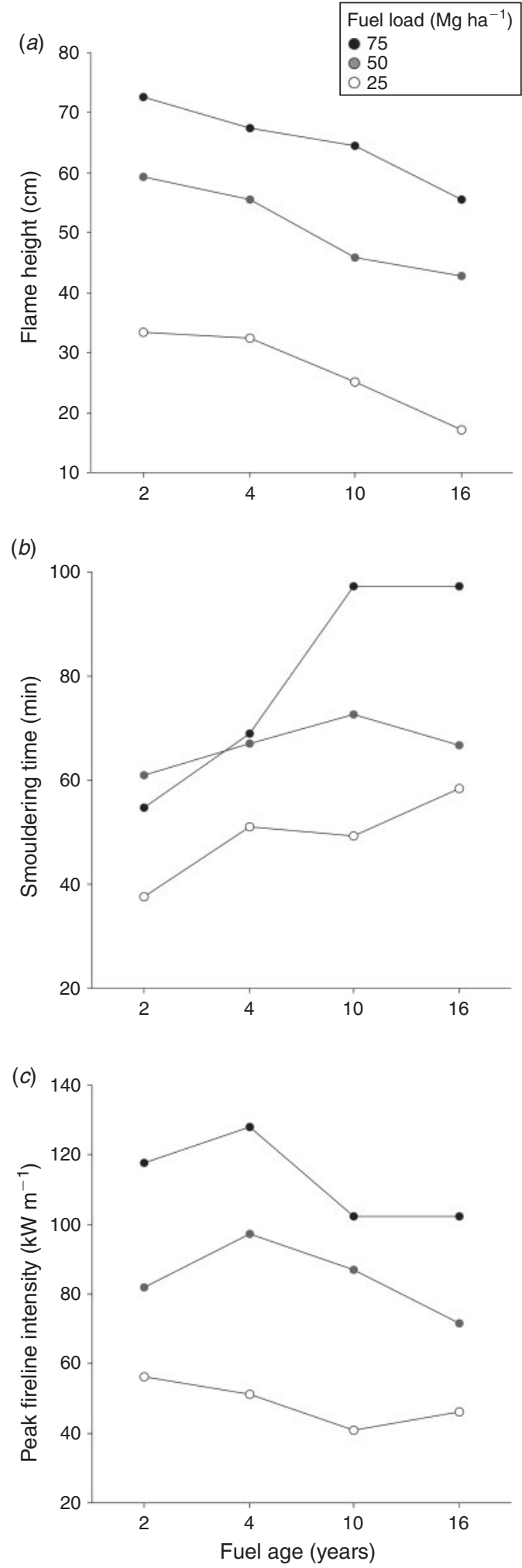

Fig. 2. The effect of fuelbed age on maximum flame height $(a)$; smouldering duration $(b)$; and peak fireline intensity (c) during laboratory burning masticated fuel loads of 25,50 and $75 \mathrm{Mg} \mathrm{ha}^{-1}$. Data are adjusted means from each GLM (general linear model). 

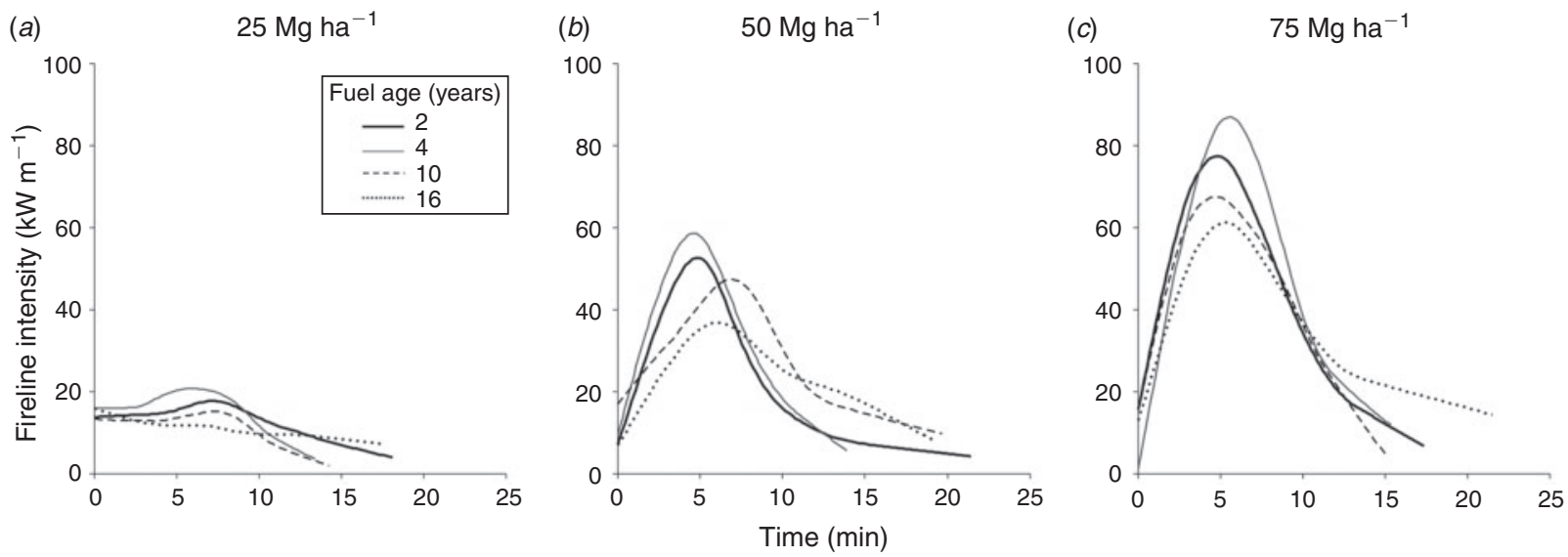

Fig. 3. Effects of fuelbed age on fireline intensity $\left(\mathrm{kW} \mathrm{m}^{-1}\right)$ during burning of masticated debris collected from sites ranging in fuel age from 2 to 16 years. Burning experiments were conducted using three different fuel loads: $25(a) ; 50(b)$; and $75(c) \mathrm{Mg}^{-1}$. Data presented are LOESS curves (using $40 \%$ of data at each LOESS regression calculation) across replicated burns $(n=3)$.

density, resulting from decomposition, has been shown to increase ignitability of individual dead twigs, but without effects on heat release (Zhao et al. 2014). Fuel heat content may also change with decomposition, likely a result of increased relative lignin concentration and mineral content (via decay of cellulose; Hyde et al. 2011). As we did not quantify heat content, we used a constant across fuel age categories to estimate fireline intensity. Although fireline intensity may have been slightly underestimated in older fuels, where higher lignin concentrations may have increased heat content, intensity was still strongly correlated with flame height, as expected. And although cellulose more readily volatises to support flaming combustion, lignin content, along with mineral content and high packing ratio, promotes smouldering combustion (Johnson and Miyanishi 2001), which was prolonged in these older fuelbeds.

Although consumption did not decrease with fuelbed age during burning, smouldering combustion increased, presumably owing to fuel particle (e.g. density and lignin: cellulose; Shafizadeh and Bradbury 1979; Costa and Sandberg 2004) or fuelbed property (e.g. increased bulk density) changes with fuelbed age. Reduced fire intensity over time may enhance long-term treatment efficacy, but longer durations of smouldering combustion may have unintended ecological or health (e.g. smoke emissions) consequences when older masticated fuels are burned (Ottmar 2014). Long-duration smouldering fires may prolong lethal heating near the base of trees or in underlying mineral soils (Busse et al. 2005), exacerbating duff combustion and potentially causing unforeseen overstorey tree mortality (Ryan and Frandsen 1991). Smouldering also tends to be a less efficient form of combustion compared with flaming, and increases in smoke production and changes to smoke chemistry (e.g. increased CO concentration, particulate matter and decreased visibility) are typically associated with smouldering fires (Sandberg et al. 2002; Ottmar 2014).

Fuel load, moisture content and the species composition of fuel burned may be the best predictors of fire behaviour in masticated fuels (Kreye et al. 2011, 2013; Brewer et al. 2013), but fuel degradation will contribute to how fuels burn over time.
As masticated fuels decompose, decreases in fuel load reduce potential energy for combustion, but our results highlight that effects of fuel aging on particle density, fuelbed composition and potentially chemistry may affect fire behaviour beyond simple reductions in fuel load. Aging fuels burned with lower fire intensity, but smouldered for longer durations even when total fuel loads were held constant. Laboratory studies with recently masticated fuels have shown the propensity for fuelbeds to burn for long durations (Busse et al. 2005), but our work is the first to reveal how these patterns change over time. Several factors may influence decomposition rates of masticated debris, but moisture is likely to be of primary importance (Enríquez et al. 1993; Prescott et al. 2004). In dry environments, slow decomposition rates may prolong post-mastication hazards. But even as fuels decay, prolonged smouldering may pose additional risks associated with long-duration heating or emissions.

Although our results show a reduction in fire intensity over time in masticated fuels, these predictions are complicated by site-level factors that will be important in determining how treatments may burn during wildfires or prescribed burns. Litter, duff or other surface fuels (Kobziar et al. 2009; Knapp et al. 2011; Kreye et al. 2013) that may remain on site since the time of mastication, or are deposited on top of the masticated fuels over time also contribute to fire behaviour. And the influence of recovering understorey and midstorey vegetation on posttreatment fire behaviour may be even more important (Kreye and Kobziar 2015). Although our results highlight the influence of fuel age on combustion, fire behaviour measurements at the laboratory scale may differ from what is observed in the field where steady-state rate of fire spread and fireline intensity may differ. The longevity of the contribution of masticated woody fuels to fire behaviour (Kreye et al. 2014b) and effects (Busse et al. 2005; Reiner et al. 2009; Knapp et al. 2011) will likely rely on how much debris was initially created (Kane et al. 2010; Kreye et al. 2014a) and how long it takes to decompose (Reed 2016). Understanding the many factors that influence fire behaviour in masticated fuels will be required to fully evaluate the efficacy of these widely used treatments. 


\section{Acknowledgements}

We acknowledge funding from the Joint Fire Science Program under project JFSP 12-1-03-31. Experiments were conducted at the Humboldt State University's Wildland Fire Laboratory. We thank the USDA Forest Service and USDI Bureau of Land Management for allowing access to masticated sites from which fuel was collected. G. Hamby, J. Tobia and C. Keller collected fuels. Laboratory assistance was provided by M. Dos Santos an E. Oliverio who were supported by the Brazilian Science Without Borders program. S. Chen provided helpful comments on an earlier version of this manuscript, and we thank two anonymous reviewers for helpful comments.

\section{References}

Battaglia MA, Rocca ME, Rhoades CC, Ryan MG (2010) Surface fue loadings within mulching treatments in Colorado coniferous forests Forest Ecology and Management 260, 1557-1566. doi:10.1016/ J.FORECO.2010.08.004

Bradley T, Gibson J, Bunn W (2006) Fire severity and intensity during spring burning in natural and masticated mixed shrub woodlands. In 'Fuels management - how to measure success: conference proceedings', 28-30 March 2006, Portland, OR. (Eds PL Andrews, BW Butler) USDA Forest Service, Rocky Mountain Research Station, Proceedings RMRS-P-41, pp. 419-428. (Fort Collins, CO)

Brewer NW, Smith AMS, Hatten JA, Higuera PE, Hudak AT, Ottmar RD, Tinkman WT (2013) Fuel moisture influences on fire-altered carbon in masticated fuels: an experimental study. Journal of Geophysical Research. Biogeosciences 118, 30-40. doi:10.1029/2012JG002079

Busse MD, Bussea MD, Fiddler GO, Shestak CJ, Powers RF (2005) Lethal soil temperatures during burning of masticated forest residues. International Journal of Wildland Fire 14, 267-276. doi:10.1071/ WF04062

Carlton DW, Pickford SG (1982) Fuelbed changes with aging of slash from ponderosa pine thinnings. Journal of Forestry 86, 91-101.

Costa FS, Sandberg D (2004) Mathematical model of a smoldering log. Combustion and Flame 139, 227-238. doi:10.1016/J.COMBUST FLAME.2004.07.009

Countryman CM (1982) Physical characteristics of some northern California brush fuels. USDA Forest Service, Pacific Southwest Forest and Range Experiment Station, General Technical Report PSW-61. (Berkeley, CA)

Enríquez S, Duarte CM, Sand-Jensen K (1993) Patterns in decomposition rates among photosynthetic organisms: the importance of detritus C : N : P content. Oecologia 94, 457-471. doi:10.1007/BF00566960

Erickson HE, Edmonds RL, Peterson CE (1985) Decomposition of logging residues in Douglas-fir, western hemlock, Pacific silver fir, and ponderosa pine ecosystems. Canadian Journal of Forest Research 15, 914-921. doi:10.1139/X85-147

Hyde JC, Smith AMS, Ottmar RD, Alvarado EC, Morgan P (2011) The combustion of sound and rotten coarse woody debris: a review. International Journal of Wildland Fire 20, 163-174. doi:10.1071/WF09113

Johnson EA, Miyanishi K (Eds) (2001) 'Forest fires: behavior and ecological effects.' (Academic Press: San Diego, CA)

Kane JM, Varner JM, Knapp EE (2009) Novel fuelbed characteristics associated with mechanical mastication treatments in northern California and south-western Oregon, USA. International Journal of Wildland Fire 18, 686-697. doi:10.1071/WF08072

Kane JM, Varner JM, Knapp EE, Powers RF (2010) Understory vegetation response to mechanical mastication and other fuels treatments in a ponderosa pine forest. Applied Vegetation Science 13, 207-220. doi:10.1111/J.1654-109X.2009.01062.X

Keane RE (2015) 'Wildland fuel fundamentals and applications.' (Springer: New York)
Knapp EE, Varner JM, Busse MD, Skinner CN, Shestak CJ (2011) Behaviour and effects of prescribed fire in masticated fuel beds. International Journal of Wildland Fire 20, 932-945. doi:10.1071/ WF10110

Kobziar LN, McBride JR, Stephens SL (2009) The efficacy of fire and fuels reduction treatments in a Sierra Nevada pine plantation. International Journal of Wildland Fire 18, 791-801. doi:10.1071/ WF06097

Kreye JK, Kobziar LN (2015) The impact of mastication on surface fire behaviour, fuels consumption, and tree mortality in pine flatwoods of Florida, USA. International Journal of Wildland Fire 24, 573-579. doi:10.1071/WF14186

Kreye JK, Varner JM, Knapp EE (2011) Effects of particle fracturing and moisture content on fire behaviour in masticated fuel beds burned in a laboratory. International Journal of Wildland Fire 20, 308-317. doi:10.1071/WF09126

Kreye JK, Kobziar LN, Zipperer WC (2013) Effects of fuel load and moisture content on fire behaviour and heating in masticated litterdominated fuels. International Journal of Wildland Fire 22, 440-445. doi:10.1071/WF12147

Kreye JK, Kobziar LN, Camp JM (2014a) Immediate and short-term response of understory fuels following mechanical mastication in a pine flatwoods site of Florida, USA. Forest Ecology and Management 313, 340-354. doi:10.1016/J.FORECO.2013.10.034

Kreye JK, Brewer NW, Morgan P, Varner JM, Smith AMS, Hoffman CM, Ottmar RD (2014b) Fire behavior in masticated fuels: a review. Forest Ecology and Management 314, 193-207. doi:10.1016/J.FORECO.2013. 11.035

Menges ES, Gordon DR (2010) Should mechanical treatments and herbicides be used as fire surrogates to manage Florida's uplands? A review. Florida Scientist 73, 147-174.

Molina DM, Galan M, Fababu DD, Garcia D, Mora JB (2009) Prescribed fire use for cost-effective fuel management in Spain. In 'Proceedings of the third international symposium on fire economics, planning, and policy: common problems and approaches', 29 April-2 May 2008, Carolina, Puerto Rico. (Ed. A Gonzalez-Caban) USDA Forest Service, Pacific Southwest Research Station, General Technical Report PSW-GTR-227, pp. 370-374 (Albany, CA)

Montiel C, Kraus D (Eds) (2010) Best practices of fire use - prescribed burning and suppression fire programmes in selected case-study regions in Europe. European Forest Institute, Research Report 24. (Joensuu, Finland)

Ottmar R (2014) Wildfire emissions, carbon, and climate: modeling fuel consumption. Forest Ecology and Management 317, 41-50. doi:10.1016/ J.FORECO.2013.06.010

Prescott CE, Blevins LL, Staley C (2004) Litter decomposition in British Columbia forests: controlling factors and influences of forestry activities. Journal of Ecosystems and Management 5, 44-57.

Reed WP (2016) Long-term fuel and vegetation responses to mechanical mastication. MSc thesis, Virginia Polytechnic Institute and State University, Blacksburg

Reiner AL, Vaillant NV, Fites-Kaufman J, Dailey SN (2009) Mastication and prescribed fire impacts on fuels in a 25 -year-old ponderosa pine plantation, southern Sierra Nevada. Forest Ecology and Management 258, 2365-2372. doi:10.1016/J.FORECO.2009.07.050

Rothermel RC (1972) A mathematical model for predicting fire spread in wildland fuels. USDA Forest Service, Intermountain Forest and Range Experiment Station, Research Paper INT-115. (Ogden, UT)

Ryan KC, Frandsen WH (1991) Basal injury from smoldering fires in mature Pinus ponderosa Laws. International Journal of Wildland Fire $\mathbf{1}$ 107-118. doi:10.1071/WF9910107

Sandberg DV, Ottmar RD, Peterson JL, Core J (2002) Wildland fire in ecosystems: effects of fire on air. USDA Forest Service Rocky 
Mountain Research Station, General Technical Report RMRS-42 Vol. 5. (Ogden, UT)

Schiks T, Thompson DK, Wotton BM (2015) Short-term effects of mastication on fuel moisture and thermal regime or boreal fuel beds. Canadian Journal of Forest Research 45, 867-876. doi:10.1139/CJFR2014-0431

Shafizadeh F, Bradbury AGW (1979) Smoldering combustion of cellulosic materials. Journal of Building Phuysics 2, 141-152. doi:10.1177/ 109719637900200304
United States Environmental Protection Agency (2013) Level III ecoregions of the continental United States: Corvallis, Oregon, United States Environmental Protection Agency - National Health and Environmental Effects Research Laboratory, map scale 1:7500 000. Available at ftp:// newftp.epa.gov/EPADataCommons/ORD/Ecoregions/us/Eco_Level_ III_US.html [Verified 23 June 2016]

Zhao W, Blauw LG, van Logtestijn RSP, Cornwell WK, Cornelissen HC (2014) Interactions between fine wood decomposition and flammability. Forests 5, 827-846. doi:10.3390/F5040827 